\title{
Atypia of Undetermined Significance in Thyroid Fine-Needle Aspiration Cytology: Pathological Evaluation and Risk Factors for Malignancy
}

\author{
Şafak Akın, ${ }^{1}$ Nafiye Helvacı, ${ }^{1}$ Neşe Çınar, ${ }^{1}$ Sevgen Önder, ${ }^{2}$ Miyase Bayraktar ${ }^{1}$
}

\author{
${ }^{1}$ Department of Endocrinology and \\ Metabolism, Hacettepe University \\ Faculty of Medicine, Ankara, Turkey \\ ${ }^{2}$ Department of Pathology, \\ Hacettepe University Faculty of \\ Medicine, Ankara, Turkey \\ Submitted: 13.03.2017 \\ Accepted: 10.04.2017 \\ Correspondence: Şafak Akın \\ Rize Eğitim ve Araştırma Hastanesi, \\ Endokrinoloji Kiliniği, Rize, Turkey \\ E-mail:safakcavus@gmail.com

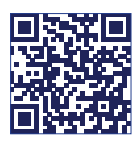 \\ Keywords: Atypia of \\ undetermined significance; \\ thyroid cancer; thyroid \\ fine-needle aspiration.
}

\begin{abstract}
Objective: This study was performed to analyze the surgical pathology results of thyroid fine-needle aspiration (FNA) cytology categorized as atypia of undetermined significance (AUS).

Methods: A retrospective analysis of 55 patients who underwent thyroid surgery between December 2007 and December 2013 as a result of a diagnosis of AUS cytology from FNA. Patient age and gender, site and size of the nodules, ultrasonographic findings, and final pathological results were analyzed.
\end{abstract}

Results: A total of 44 female patients and II male patients were included in this study. Among the 55 cases, 27 (49.I\%) had final diagnosis of malignancy and 28 (50.9\%) had benign lesions according to pathological evaluation. Both univariate and multivariate analysis revealed that only ultrasonographic finding of suspected malignancy was associated with malignant pathology.

Conclusion: The risk for malignancy should be determined in the initial stage and high-risk patients with cytology classified as AUS should be recommended for surgery. In this study, the patients had a high preoperative risk of malignancy; thus, our pathological results had a high rate of malignancy.

\section{INTRODUCTION}

Thyroid cancer is the most prevalent endocrine cancer. The 10-year life expectancy is $90 \%$ to $95 \%$. More than $80 \%$ of all cases of thyroid cancer are differentiated thyroid carcinoma. Fine-needle aspiration (FNA) cytology is the most useful method to differentiate between benign and malignant thyroid nodules. ${ }^{[1-3]}$ The National Cancer Institute published the Bethesda System for Reporting Thyroid Cytopathology, which recommended a cytological classification of thyroid nodules: nondiagnostic, benign, atypia of undetermined significance (AUS) or follicular lesion with undetermined significance, follicular neoplasm or suspicious for follicular neoplasm, suspicious for ma- lignancy, and malignant tumor. ${ }^{[4-6]}$ Earlier studies have reported that $20 \%$ of thyroid nodules were categorized as AUS based on cytological examination of an FNA biopsy specimen. ${ }^{[7,8]}$ There is a $5 \%$ to $15 \%$ risk of malignancy in these cases. ${ }^{[9]}$ Since it is difficult to determine whether atypia detected in cytological examination is benign or malignant, other clinical characteristics should be taken into consideration.

The aim of this study was to analyze the surgical pathology results of cases in which FNA cytology was reported as AUS. 


\section{MATERIAL AND METHODS}

The medical files of 55 patients (female, $n=44$ and male, $\mathrm{n}=1 \mathrm{I}$; age range: $22-73$ years) who underwent surgery between December 2007 and December 2013 because FNA cytology results were reported as AUS were analyzed retrospectively.

At first preoperative evaluation, all patients underwent thyroid function test and thyroid ultrasound scan. An endocrinologist performed ultrasound-guided FNA biopsy using a 25-G needle. FNA cytology was evaluated using the Bethesda classification. Clinicopathological data included patient age and gender, nodule size and location, ultrasound findings, and final pathology reports. Presence of ultrasonographically detected irregular contours, microcalcification, and internal vascularization was accepted as an indication of malignancy.

Statistical analysis was conducted using SPSS for Windows, Version I5.0 (SPSS Inc., Chicago, IL, USA). Data were expressed as mean $\pm S D$. Normality of distribution was evaluated using the Kolmogorov-Smirnov test. Statistical significance between subgroups was determined using the chi-square and Student's t-tests. Logistic regression analysis was used to evaluate characteristics and the presence of malignancy. $\mathrm{P}<0.05$ was accepted as the cut-off value for statistical significance.

\section{RESULTS}

The median age of the study population was 48 years (range: 22-73 years). The basic characteristics of the 55

Table I. Basic characteristics of the patients

\begin{tabular}{|c|c|}
\hline Variables & $n=55$ \\
\hline Age (mean $\pm S D)$ & $48.6 \pm 12.5$ \\
\hline Gender (female/male) & $44 / 11$ \\
\hline \multicolumn{2}{|l|}{ Laterality of the nodule } \\
\hline Left & $13(23.6)$ \\
\hline Right & $10(18.2)$ \\
\hline Bilateral & $32(58.2)$ \\
\hline Diameter of the nodule (mm, [median, range]) & $22(5-75)$ \\
\hline \multicolumn{2}{|l|}{ Preoperative thyroid-stimulating hormone level } \\
\hline (ulU/mL) & $2.08 \pm 2.6$ \\
\hline \multicolumn{2}{|l|}{ Pathology } \\
\hline Papillary carcinoma & $9(33)$ \\
\hline Papillary microcarcinoma & $10(37)$ \\
\hline Follicular carcinoma & $3(11)$ \\
\hline Medullary carcinoma & I (4) \\
\hline Other & $4(15)$ \\
\hline
\end{tabular}

study patients with cytological result of AUS classification are summarized in Table I. All patients underwent total thyroidectomy. Histopathological evaluation revealed the presence of malignancy in 27 (49.1\%) patients, and benign lesion in 28 (50.9\%) patients. Of those with malignant lesions, 9 had papillary carcinoma, 10 had papillary microcarcinoma, 3 had follicular carcinoma, 3 had well-differentiated thyroid neoplasm with undetermined malignant potential, I had medullary thyroid carcinoma, and I had papillary carcinoma associated with well-differentiated thyroid neoplasm. The benign lesions were multinodular goiters $(n=\mid 4)$, follicular adenoma $(n=3)$, lymphocytic thyroiditis $(n=10)$, and dyshormoogenetic goiter $(n=1)$. The most frequently seen malignant tumor was thyroid carcinoma $(70.4 \%)$, and the most common benign tumor was multinodular goiter (50\%). Of the 27 cases of malignant lesion, 8 were multicentric tumor, 2 were bilateral, and II were lymphocytic thyroiditis. One of the 9 cases of papillary carcinoma had lymph node metastasis. The mean diameter of all tumors was $14.7 \pm 12.5 \mathrm{~mm}$ (range: I-40 $\mathrm{mm})$.

One patient who had multinodular goiter had a family history of thyroid cancer. The concomitant pathologies were prolactinoma $(n=2)$, tongue cancer $(n=1)$, breast cancer $(n=I)$, cervical cancer $(n=I)$, and lymphoma $(n=I)$.

Clinical characteristics of the patients with benign and malignant lesions are provided in Table 2. The results of univariate analysis did not determine any difference between benign and malignant groups according to patient gender or age, or site of the nodule. Univariate and multivariate analysis indicated that malignant nodules were smaller than benign tumors. The number of ultrasonographic findings with suspected malignancy was greater among cases with malignant pathology Multivariate analysis of parameters demonstrated that only ultrasonographic finding of suspected malignancy was associated with malignant pathology (Table 3).

\section{DISCUSSION}

FNA biopsy is used to assess thyroid nodules. Histological examination of FNA biopsy specimens reveals benign lesions in $60 \%$ to $70 \%$ of cases, while in $20 \%$ to $30 \%$, results indicate suspected follicular neoplasia, suspected malignancy, or malignant cytology. ${ }^{[6,10]}$ Previous studies have reported that finding of AUS was reported in $2 \%$ to $18 \%$ of cases. ${ }^{[14]}$ Recently, Onder et al. reported $6.7 \%$ AUS and $18.9 \%$ malignant cytology in a total of 6310 FNA thyroid biopsy specimens. Increased incidence of AUS has been reported in various studies. ${ }^{[1-13]}$ In this study, malignant tumors were more frequent. This result may be due to the fact that our study population consisted only of patients who underwent surgery. A high malignancy rate may be the result of many factors, including heterogeneity of 
Table 2. Clinical characteristics of patients according to nodule diagnosis

\begin{tabular}{|c|c|c|c|}
\hline Variables & Benign $(n=28)$ & Malignant $(n=27)$ & $\mathbf{p}$ \\
\hline Gender & & & 0.281 \\
\hline Female & $24(54.5)$ & $20(45.5)$ & \\
\hline Male & $4(14.3)$ & $7(63.6)$ & \\
\hline Age (years) & & & 0.937 \\
\hline$<40$ & $7(50)$ & $7(50)$ & \\
\hline$\geq 40$ & $2 I(5 \mid .2)$ & $20(48.8)$ & \\
\hline Mean \pm SD & $50.4 \pm 13.1$ & $46.7 \pm 11.7$ & \\
\hline Diameter of the nodule $(\mathrm{mm})$ & $32.4 \pm 17.7$ & $21.6 \pm 12.1$ & 0.018 \\
\hline Laterality of the nodule & & & 0.410 \\
\hline Left & $7(70.0)$ & $3(30.0)$ & \\
\hline Right & $6(46.2)$ & $7(53.8)$ & \\
\hline Bilateral & $15(46.9)$ & $17(53.1)$ & \\
\hline Ultrasound suspicion of malignancy & $6(21.4)$ & $19(70.4)$ & $<0.001$ \\
\hline
\end{tabular}

Table 3. Multivariate analysis of clinical predictors of malignancy

\begin{tabular}{lccrc}
\hline Variables & Hazard ratio & & Risk ratio (95\% CI) & P \\
\cline { 3 - 5 } & & Lower limit & Upper limit \\
\hline Age $<40$ years vs. $\geq 40$ years & 0.40 & 0.06 & 2.41 & 0.32 \\
Gender & 0.39 & 0.07 & 2.24 & 0.29 \\
Diameter of the nodule & 1.05 & 0.99 & 1.12 & 0.06 \\
Ultrasound suspicion of malignancy & 5.85 & 1.39 & 24.57 & 0.01 \\
\hline
\end{tabular}

AUS, or differences in interpretation of the cytological results by pathologists. ${ }^{[9]}$ In our study, papillary carcinoma was the most frequently seen malignancy. Previous studies have reported that incidence rate of papillary carcinoma and follicular carcinoma were similar and that the follicular variant of papillary carcinoma was the most frequently seen. ${ }^{[15-17]}$

In the present study, we found no significant difference between malignant and benign nodules according to patient age or gender. Other authors have also indicated the lack of any correlation between age and increase in the risk of malignancy. ${ }^{[15,17,18]}$ However, in one study, patient age was demonstrated to be a marker for malignancy. ${ }^{[8,19-21]}$ Male gender has also been found to be associated with malignancy in some studies, ${ }^{[19,22]}$ while others found no difference between genders in terms of malignancy. ${ }^{[15,18,23]}$

The results of multivariate analysis performed for this study demonstrated that suspicion of malignancy detected ultrasonographically was associated with risk of malignancy. Gharib et al. ${ }^{[10]}$ reported that sonographic characteristics of malignant thyroid nodules were irregular boundaries, the presence of calcification, hypoechogenicity, vascular abnormalities, and increased size. In another study, it was reported that risk of malignancy was $66.7 \%$ when 2 features that suggest suspicion of malignancy are detected in ultrasonographic examinations. ${ }^{[24]}$

It was recommended in the National Cancer Institute guideline that evaluation of atypia results may benefit from recurrent aspiration or correlation with clinical and radiological findings. ${ }^{[25]}$ The recommended management in cases with AUS is to repeat aspiration within 3 to 6 months. Surgery is indicated in cases of recurrent atypia or follicular lesion of undetermined significance. ${ }^{[6]}$ Overuse of the terms atypia and follicular lesion of undetermined significance has been demonstrated. ${ }^{[26]}$ Surgery is generally considered for nodules with greater potential for malignancy or recurrent finding of AUS. Onder et al. ${ }^{[9]}$ reported that $53.4 \%$ of recurrent aspiration cases were found to be benign. In this study, we did not analyze recurrent cytological examinations and risk of malignancy. Another limitation of our study was small size of the sample.

In conclusion, clinical and ultrasonographic findings should 
be considered in combination when cytological examination has result of AUS. The risk of malignancy was high in our patients, and for this reason, the malignancy rate in the pathological results in this study was also high. It is recommended that malignancy risk should be determined in the initial evaluation of patients with cytology in AUS category, and high-risk patients should be referred to surgery. There is a need for studies that include a larger number of patients to determine the risk of malignancy in these patients.

\section{Ethics Committee Approval}

Ethics Committee of Hacettepe University School of Medicine, approval number: LUT I2/I54-02.

\section{Informed Consent}

The study design was retrospective observational study.

Peer-review

Internally peer-reviewed.

Authorship Contributions

Concept: Ş.A.; Design: Ş.A.; Data collection \&/or processing: Ş.A., N.H., N.Ç.; Analysis and/or interpretation: Ş.A.; Literature search: Ş.A., M.B.; Writing: Ş.A.; Critical review: Ş.A., M.B.

\section{Conflict of Interest}

None declared.

\section{REFERENCES}

1. Baloch ZW, Sack MJ, Yu GH, Livolsi VA, Gupta PK. Fine-needle aspiration of thyroid: an institutional experience. Thyroid 1998;8:565-9.

2. Werga P, Wallin G, Skoog L, Hamberger B. Expanding role of fineneedle aspiration cytology in thyroid diagnosis and management. World J Surg 2000;24:907-12. [CrossRef]

3. American Thyroid Association (ATA) Guidelines Taskforce on Thyroid Nodules and Differentiated Thyroid Cancer, Cooper DS, Doherty GM, Haugen BR, Kloos RT, Lee SL, Mandel SJ, et al. Revised American Thyroid Association management guidelines for patients with thyroid nodules and differentiated thyroid cancer. Thyroid 2009;19:1167-214. [CrossRef]

4. Baloch ZW, Cibas ES, Clark DP, Layfield LJ, Ljung BM, Pitman MB, et al. The National Cancer Institute Thyroid fine needle aspiration state of the science conference: a summation. Cytojournal 2008;5:6.

5. Cibas ES, Ali SZ. The Bethesda System for Reporting Thyroid Cytopathology. Thyroid 2009;19:1159-65. [CrossRef]

6. Cibas ES, Ali SZ; NCI Thyroid FNA State of the Science Conference. The Bethesda System For Reporting Thyroid Cytopathology. Am J Clin Pathol 2009;132:658-65. [CrossRef]

7. Hamburger JI. Diagnosis of thyroid nodules by fine needle biopsy: use and abuse. J Clin Endocrinol Metab 1994;79:335-9. [CrossRef]

8. Kim ES, Nam-Goong IS, Gong G, Hong SJ, Kim WB, Shong YK. Postoperative findings and risk for malignancy in thyroid nodules with cytological diagnosis of the so-called "follicular neoplasm". Korean J Intern Med 2003;18:94-7. [CrossRef]

9. Onder S, Firat P, Ates D. The Bethesda system for reporting thyroid cytopathology: an institutional experience of the outcome of indeterminate categories. Cytopathology 2014;25:177-84. [CrossRef]

10. Gharib H, Goellner JR. Fine-needle aspiration biopsy of the thyroid: an appraisal. Ann Intern Med 1993;118:282-9. [CrossRef]

11. Ohori NP, Schoedel KE. Variability in the atypia of undetermined significance/follicular lesion of undetermined significance diagnosis in the Bethesda System for Reporting Thyroid Cytopathology: sources and recommendations. Acta Cytol 2011;55:492-8. [CrossRef]

12. Marchevsky AM, Walts AE, Bose S, Gupta R, Fan X, Frishberg $D$, et al. Evidence-based evaluation of the risks of malignancy predicted by thyroid fine-needle aspiration biopsies. Diagn Cytopathol 2010;38:252-9.

13. Luu MH, Fischer AH, Stockl TJ, Pisharodi L, Owens CL. Atypical follicular cells with equivocal features of papillary thyroid carcinoma is not a low-risk cytologic diagnosis. Acta Cytol 2011;55:526-30.

14. VanderLaan PA, Marqusee E, Krane JF. Clinical outcome for atypia of undetermined significance in thyroid fine-needle aspirations: should repeated fna be the preferred initial approach? Am J Clin Pathol 2011;135:770-5. [CrossRef]

15. Rago T, Di Coscio G, Basolo F, Scutari M, Elisei R, Berti P, et al. Combined clinical, thyroid ultrasound and cytological features help to predict thyroid malignancy in follicular and Hupsilonrthle cell thyroid lesions: results from a series of 505 consecutive patients. Clin Endocrinol (Oxf) 2007;66:13-20.

16. Tysome JR, Chandra A, Chang F, Puwanarajah P, Elliott M, Caroll P, et al. Improving prediction of malignancy of cytologically indeterminate thyroid nodules. Br J Surg 2009;96:1400-5. [CrossRef]

17. Sippel RS, Elaraj DM, Khanafshar E, Kebebew E, Duh QY, Clark $\mathrm{OH}$. Does the presence of additional thyroid nodules on ultrasound alter the risk of malignancy in patients with a follicular neoplasm of the thyroid? Surgery 2007;142:851-7. [CrossRef]

18. Wiseman SM, Baliski C, Irvine R, Anderson D, Wilkins G, Filipenko $\mathrm{D}$, et al. Hemithyroidectomy: the optimal initial surgical approach for individuals undergoing surgery for a cytological diagnosis of follicular neoplasm. Ann Surg Oncol 2006;13:425-32. [CrossRef]

19. Baloch ZW, Fleisher S, LiVolsi VA, Gupta PK. Diagnosis of "follicular neoplasm": a gray zone in thyroid fine-needle aspiration cytology. Diagn Cytopathol 2002;26:41-4. [CrossRef]

20. Schlinkert RT, van Heerden JA, Goellner JR, Gharib H, Smith SL, Rosales RF, et al. Factors that predict malignant thyroid lesions when fine-needle aspiration is "suspicious for follicular neoplasm". Mayo Clin Proc 1997;72:913-6. [CrossRef]

21. Tyler DS, Winchester DJ, Caraway NP, Hickey RC, Evans DB, Indeterminate fine-needle aspiration biopsy of the thyroid: identification of subgroups at high risk for invasive carcinoma. Surgery 1994;116:1054-60.

22. Tuttle RM, Lemar H, Burch HB. Clinical features associated with an increased risk of thyroid malignancy in patients with follicular neoplasia by fine-needle aspiration. Thyroid 1998;8:377-83. [CrossRef]

23. McHenry CR, Thomas SR, Slusarczyk SJ, Khiyami A. Follicular or Hürthle cell neoplasm of the thyroid: can clinical factors be used to predict carcinoma and determine extent of thyroidectomy? Surgery 1999;126:798-802. [CrossRef]

24. Ryu YJ, Jung YS, Yoon HC, Hwang MJ, Shin SH, Cho JS, et al. Atypia of undetermined significance on thyroid fine needle aspiration: surgical outcome and risk factors for malignancy. Ann Surg Treat Res 2014;86:109-14. [CrossRef]

25. Baloch ZW, LiVolsi VA, Asa SL, Rosai J, Merino MJ, Randolph G, et 
al. Diagnostic terminology and morphologic criteria for cytologic diagnosis of thyroid lesions: a synopsis of the National Cancer Institute Thyroid Fine-Needle Aspiration State of the Science Conference. Diagn Cytopathol 2008;36:425-37. [CrossRef]
26. Kholová I, Ludvíková M. Thyroid atypia of undetermined significance or follicular lesion of undetermined significance: an indispensable Bethesda 2010 diagnostic category or waste garbage? Acta Cytol 2014;58:319-29. [CrossRef]

\section{Tiroid İnce lğne Aspirasyon Sitolojisinde Önemi Belirsiz Atipi: Malignite Risk Faktörleri ve Patolojik Değerlendirme}

Amaç: Bu çalışma ile ince iğne aspirasyon sitoloji sonucu önemi belirsiz atipi olan ve cerrahi uygulanan hastaların patoloji sonuçlarının incelenmesi amaçlanmıştır.

Gereç ve Yöntem: Aralık 2007-Aralık 2013 tarihleri arasında ince iğne aspirasyon sitoloji sonucu önemi belirsiz atipi olan ve cerrahi uygulanan 55 hastanın tıbbi kayıtları geriye dönük olarak analiz edildi. Yaş, cinsiyet, nodüllerin yer ve büyüklüğü, ultrasonografik bulguları ve nihai patolojik sonuçları değerlendirildi.

Bulgular: Çalışmamızda 44 kadın hasta ve II erkek hasta değerlendirildi. Patolojik değerlendirmede 55 olgunun 27’sinde (\%49.I) malignite tanısı kondu, 28 'inde (\%50.9) benign lezyon saptandı. Hem tek değişkenli hem de çok değişkenli analiz, yalnızca ultrasonografik bulguların malign patolojiyle ilişkili olduğunu gösterdi.

Sonuç: Önemi belirsiz atipi sitolojisine sahip hastalarda malignite riskinin ilk değerlendirmede belirlenmesi ve yüksek riskli hastaların cerrahiye gönderilmesi önemlidir. Bu çalışmada hastalarımızın ameliyat öncesi malignite riski yüksekti ve bu nedenle patolojik sonuçlarımızda malignite daha yüksek tespit edildi.

Anahtar Sözcükler: Önemi belirsiz atipi; tiroid ince iğne aspirasyonu; tiroid kanseri. 